\title{
PHYTOCHEMISTRY AND ANTIFUNGAL POTENTIAL OF Datura inoxia Mill. ON SOIL PHYTOPATHOGEN CONTROL
}

\author{
FITOQUÍMICA E POTENCIAL ANTIFÚNGICO DE Datura inoxia Mill. NO \\ CONTROLE DE FITOPATÓGENOS DE SOLO
}

\begin{abstract}
Rosemary MATIAS ${ }^{1}$; Valtecir FERNANDES ${ }^{1}$; Bianca Obes CORRÊA ${ }^{2}$; Silvia Rahe PEREIRA ${ }^{2}$; Ademir Kleber Morbeck de OLIVEIRA ${ }^{1^{*}}$

1. Postgraduate Program in Environment and Regional Development, University Anhanguera-Uniderp, Campo Grande, MS, Brazil; 2. Postgraduate Program in Agro-Industrial Production and Management, University Anhanguera-Uniderp, Campo Grande, MS, Brazil. *akmorbeckoliveira@gmail.com
\end{abstract}

\begin{abstract}
The application of chemical pesticides for the control of fungal diseases results in impacts on the environment and human health. The use of vegetal extracts with antifungal properties for the proper management of crops becomes a viable alternative, mainly for organic and family farming. The objective of this study was to carry out the phytochemical evaluation of Datura inoxia, evaluating its antifungal potential against the mycelial growth of Fusarium solani and Sclerotinia sclerotiorum. The extracts, aqueous and ethanolic, obtained from the leaves of the plant collected in areas of the municipality of Campo Grande, Mato Grosso do Sul, were submitted to phytochemical prospecting and quantification of flavonoids and total phenols. It was evaluated its antifungal activity at concentrations of 800, 1200, 1600, 2000, and $2400 \mu \mathrm{g} 100$ $\mathrm{mL}^{-1}$. Each concentration was separately incorporated into BDA agar, poured into Petri dishes, and inoculated with the mycelial disc of the fungus. The diameter of the colonies were measured daily. Two solutions were prepared as control, one containing the solvent added to PDA medium (ethanol solution), and another with only PDA medium (without $D$. inoxia extract, control). In both extracts were found the same diversity of secondary metabolites (nine classes). The ethanolic extract, a solvent of lower polarity than water, was more efficient in the extraction of these constituents. Alkaloids and phenolic compounds were the most frequent compounds $(100 \%)$. In relation to antifungal activity, the ethanolic extract provided $100 \%$ inhibition of mycelial growth of Sclerotinia sclerotitorum in all concentrations, relative to the control. On the other hand, the growth of Fusarium solani was only negatively affected at the highest concentrations of 800 and $1200 \mu \mathrm{mL}^{-1} 100 \mathrm{~mL}^{-1}$. The antifungal potential of Datura inoxia was probably related to the abundance of alkaloids and phenolic compounds in its chemical constitution that negatively effects the development of the vegetative mycelium.
\end{abstract}

KEYWORDS: Phytofungicide. Phenolic compounds. Fusarium solani. Sclerotinia sclerotiorum.

\section{INTRODUCTION}

The species Datura inoxia Mill. (Solanaceae), commonly called angel's trumpet, devil's trumpet, and buenas tardes, among other popular names, has a herbaceous or sub-shrub way of life, reaching up to $2 \mathrm{~m}$ (height) and is considered an annual plant when in dry environments or a perennial when environmental conditions are favourable (BURKILL, 2000; BONDE, 2001). It is native to Central America but is considered to be a naturalised plant in Brazil, and is found in anthropogenic areas in Caatinga of Bahia and of Pernambuco states (FLORA DO BRASIL, 2020). Due to its cultivation, the species has also been established in natural areas as an invasive species. Its ornamental features and beautiful flowers with a sweet odour which open at night have led it to be cultivated in gardens, and for this reason, it is widespread to all continents (BURKILL, 2000; BONDE, 2001).

Most people who grow this plant do not know that it is considered to be extremely toxic and has caused many accidents due to ingestion of their leaves. The plant is used in shamanistic rituals as an instrument to achieve illumination and also to obtain a hallucinogenic effect by drug users. There are phytotherapeutic uses, with the plant used to treat impotence, asthma, and diarrhoea, among other uses. However, it produces unpleasant results, such as disorientation, amnesia, and blurred vision, among other effects, and an overdose can result in death (SCHULTES; HOFMANN, 1992; BURKILL, 2000; BONDE, 2001).

The species has a number of active phytochemicals, including atropine, hyoscyamine, hyoscine, scopolamine, and meteloidine (GUPTA; BAGCHI; RAY, 1991), with a high concentration of alkaloids in the tissues, which varies according to 
the environment (BURKILL, 2000). Due to its diversity of metabolites, it is a species that presents a potential to be tested for use in different situations, such as in the control of phytopathogenic fungi that affect different crops and is responsible for economic losses in agricultural production.

Fusarium solani (Mart.) Sacc. and Sclerotinia sclerotiorum (Lib.) de Bary, are phytopathogens found in the soil and have been considered a problem because they produce resistance structures and can survive for several years (BUENO; AMBRÓSIO; SOUZA, 2007). According to Celoto et al. (2008), different kinds of chemical products are used for controlling it; however, their incorrect application leads to several impacts on the environment and human health, and may also lead to a selection of resistant pathogens to agrotoxics. Because of that, the use of natural products to control plant diseases is becoming a promising alternative to reduce using agrotoxics (ZACARONI et al., 2009) because certain vegetal extracts have antifungal potential and may be used as a model to synthesise new fungicides or be directly applied by the producer (CELOTO et al., 2008; OLIVEIRA et al. 2017). Silva et al. (2009) also state that the use of vegetal extracts to control or inhibit phytopathogens represents a viable alternative for organic and family farmers common in certain regions.

In the state of Mato Grosso do Sul, farmer families have contributed to developing local agribusiness, such as providing healthy food for families (SANGALLI; SCHLINDWEIN, 2013) through the use of more environmentally balanced practices, contributing to culture diversification, and reducing the use of chemical products (PADUA; SCHLINDWEIN; GOMES, 2013). The study of plants with potential use (insecticide, bactericide and fungicide) it is important for use in sustainable activities related to family farming. Thus, the aim of this study was to perform phytochemical and antioxidant analysis of the Datura inoxia, and assess its antifungal potential on the mycelial growth of Fusarium solani and Sclerotinia sclerotiorum.

\section{MATERIAL AND METHODS}

Leaves of Datura inoxia were collected in August 2016 from 31 plants found in areas in the countryside of Campo Grande (Latitude $-20^{\circ} 26^{\prime}$ 34", Longitude $-54^{\circ} 38^{\prime}$ 47". Altitude 532 meters), in the state of Mato Grosso do Sul, Brazil. Botanic material at the same vegetative stage was collected during three days, in the morning period, and stored in paper bags and transported to the Plant
Morphology Laboratory at the University in Campo Grande City, and the specimen's samples deposited in the Herbarium of the Institution.

\section{Phytochemical analysis}

The collected plant material, after excluding old or damaged leaves, was dried in a circulating air oven at $40^{\circ} \mathrm{C}$ (MARCONI ${ }^{\circledR}$, MA35), and finely ground in a Wiley mill (Model MA048, MARCONI $\left.^{\circledR}\right)$. Secondary metabolites were extracted from the powder (500 g) using distilled water in an ultrasonic bath (Ultrasonic Cleaner $\AA$ ) for 60 minutes, followed by extraction by steady static maceration for seven days. The resulting solution was filtered, and the solvent was distilled with the rotary evaporator $\left(45\right.$ to $\left.50^{\circ} \mathrm{C}\right)$. The final drying in a desiccator under reduced pressure resulted in $17 \mathrm{~g}$ of aqueous extract $\left(\mathrm{ExtH}_{2} \mathrm{O}\right)$. The same procedure was used to obtain $32 \mathrm{~g}$ of the ethanolic extract (ExtEtOH), but the extraction occurred for ten days. Both extracts were submitted to chemical and fungicide analysis.

Phytochemical prospection with $\mathrm{ExtH}_{2} \mathrm{O}$ and ExtEtOH were done through characterisation reactions to determine the class of secondary metabolites (Table 1), all analyses were performed in triplicate, following and adapting the methodology by Matos (2009) and Simões et al. (2017).

For the results of the assays, the alterations in the colour or precipitation were observed when compared with the control, following the method of Fontoura et al. (2015). Strongly positive $(+++=$ $100 \%)$, moderately positive $(++=50 \%)$, weakly positive $(+=25 \%)$, and partially positive $( \pm=10 \%)$. Whether only haze or partially changed colour also the absence of colour or precipitation was considered as negative (-). The intensity of colour or precipitation indicated the increased concentration of each class of secondary metabolite. Extracts were submitted to Bial, Seliwanoff, Barfoed, and Iodine tests for sugar classification (REMIÃO; SIQUEIRA; AZEVEDO, 2003). To confirm the reducing sugars, an analysis of soluble solids was determined by means of a digital refractometer (Model 45 RTD- refractometer), and the results were expressed in ${ }^{\circ}$ Brix, corrected for $20^{\circ} \mathrm{C}$.

In order to confirm the major constituents, $100 \mu \mathrm{m} \mathrm{mL} \mathrm{m}^{-1}$ of the extracts were analysed by a scanning spectrophotometer (Model 800, FEMTO $\left.{ }^{\circledR}\right)$. Samples absorption aspects were measured from the 200 to $750 \mathrm{~nm}$ region using quartz cuvettes (Hellma, Müllheim, Germany) and repeated in triplicate (SILVERSTEIN; WEBSTER; KIEMLE, 2007). 
Table 1. Methods of analysis of secondary metabolite classes, based on Matos (2009) and Simões et al. (2017) Constituents Analysis method

\begin{tabular}{|c|c|c|c|c|}
\hline Constituents & \multicolumn{4}{|c|}{ Analysis method } \\
\hline \multirow{3}{*}{ Phenolic compounds } & \multicolumn{4}{|c|}{$\mathrm{FeCl}_{3} 2 \%$ Solution } \\
\hline & \multicolumn{4}{|c|}{ Lead acetate $10 \%$ Solution } \\
\hline & \multicolumn{4}{|c|}{ Copper acetate $4 \%$ Solution } \\
\hline & \multicolumn{4}{|c|}{$2 \%$ gelatin solution in physiological solution } \\
\hline Tannins & \multicolumn{4}{|c|}{ Albuminous solution } \\
\hline Flavonoids & \multicolumn{4}{|c|}{$\begin{array}{l}\text { Cyanidee reaction, Shinoda reaction or hydrogenation. Reaction with concentrated } \\
\text { sulfuric acid. Confirmatory: Wilson's citroboric reaction }\end{array}$} \\
\hline \multirow{2}{*}{ Anthocyanins } & \multicolumn{4}{|c|}{ Middle colour } \\
\hline & Acids pH 2-3 & neutral pH & $\mathrm{pH} 8-9$ & $\mathrm{pH} 11$ \\
\hline $\begin{array}{l}\text { Anthocyanin and } \\
\text { anthocyanidins }\end{array}$ & Red & $\begin{array}{l}\text { No noticeable } \\
\text { colour changes }\end{array}$ & Lilac & Purple blue \\
\hline $\begin{array}{l}\text { Flavones, flavonoids and } \\
\quad \text { xanthones }\end{array}$ & $\begin{array}{l}\text { No noticeable } \\
\text { colour changes }\end{array}$ & $\begin{array}{l}\text { No noticeable } \\
\text { colour changes }\end{array}$ & $\begin{array}{l}\text { No noticeable colour } \\
\text { changes }\end{array}$ & Yellow \\
\hline Chalcones and aurones & Red & $\begin{array}{l}\text { No noticeable } \\
\text { colour changes }\end{array}$ & $\begin{array}{l}\text { No noticeable colour } \\
\text { changes }\end{array}$ & Purple-red \\
\hline Flavonols & $\begin{array}{l}\text { No noticeable } \\
\text { colour changes }\end{array}$ & $\begin{array}{l}\text { No noticeable } \\
\text { colour changes }\end{array}$ & $\begin{array}{l}\text { No noticeable colour } \\
\text { changes }\end{array}$ & Red-orange \\
\hline Free coumarins & \multicolumn{4}{|c|}{$10 \% \mathrm{NaOH}$ solution and $10 \% \mathrm{KOH}$ solution and UV light test } \\
\hline Anthraquinone & \multicolumn{4}{|c|}{ Borntrager reagente } \\
\hline Steroids & \multicolumn{4}{|c|}{ Liebermann-Burchard test } \\
\hline Triterpenes & \multicolumn{4}{|c|}{ Liebermann-Burchard e Salkowski test } \\
\hline Alkaloids & \multicolumn{4}{|c|}{$\begin{array}{l}\text { Dragendorff reagent; Hager reagent; Mayer reagent; Bertrand reagent; Reinecke's } \\
\text { salt }\end{array}$} \\
\hline Saponins & \multicolumn{4}{|c|}{ Foam test and Olive oil test } \\
\hline Cyanogenic heterosides & \multicolumn{4}{|c|}{ Guignard technique (sodium picrate) } \\
\hline Cardiotonic heterosides & \multicolumn{4}{|c|}{ Pesez reaction; Keller-Killiani test; Baljet reaction; Raymond reaction } \\
\hline Reducing sugar & \multicolumn{4}{|c|}{ Molisch's test; Barfoed's test; Seliwanoffs test; Fehling's test and Benedict reagent } \\
\hline
\end{tabular}

\section{Total phenol and flavonoids classification}

The ExtH $\mathrm{H}_{2} \mathrm{O}$ and ExtEtOH (100 mg each) were used to quantify the total phenol (TP) by the Folin-Ciocalteu method using gallic acid (10 to 350 $\left.\mathrm{mg} \mathrm{mL}^{-1}\right)$ as a standard, and a $(\mathrm{y}=0.781 \mathrm{x}-0.0031$; $\mathrm{R}^{2}=0.9959$ ) calibration curve was used (SOUSA et al., 2007). Flavonoid quantification was performed based on aluminum chloride methodology with a standard quercetin $\left(\mathrm{y}=0.132 \mathrm{x}+0.0353 \mathrm{R}^{2}=\right.$ 0.9949) (PEIXOTO SOBRINHO et al., 2008).

The experimental design of both quantifications has three replicates for each concentration, and the calculation of averages was followed by the standard deviation.

\section{Antifungal activity}

The fungi used in this study were Fusarium solani and Sclerotinia sclerotiorum, assigned by the Microbiology and Phytopathology Laboratory, Campo Grande. A stock solution was prepared containing $0.2 \mathrm{~g}$ of $\mathrm{ExtH}_{2} \mathrm{O}$ and ExtEtOH from the Datura inoxia leaves in $100 \mathrm{~mL}$ (water or ethanol), and all solutions were prepared from this stock. From this solution with $0.4,0.6,0.8,1.0$, and 1.2
$\mathrm{mL}$ were separated into fondant PDA (PotatoDextrose-Agar) culture medium until reaching a volume of $100 \mathrm{~mL}$, where concentrations of 800 , $1200,1600,2000$, and $2400 \mu \mathrm{g} 100 \mathrm{~mL}^{-1}$ were obtained. Two solutions were prepared as control, one containing the solvent added to PDA medium $\left(2400 \mu \mathrm{g} 100 \mathrm{~mL}^{-1}\right)$ and named ethanol solution, and another with only PDA medium (without $D$. inoxia extract, control).

Four Petri dishes of each concentration were prepared with $90 \mathrm{~mm}$ in a volume corresponding to $10 \mathrm{~mL}$ per plate. After solidification, a mycelium disc, with a $5 \mathrm{~mm}$ diameter was placed in the centre of each plate. Later, the plates were covered and sealed with plastic film and kept in a growth chamber at $25^{\circ} \mathrm{C}$ with a 12 -hour photoperiod.

The mycelial growth evaluation was performed through daily measurements of the colonies' diameter, obtained by the average of two opposed measurements and continued until the control group reached the edge of the Petri plate.

Based on the obtained data, the growth inhibition percentage (GIP) was calculated by the formula: 


$$
\mathrm{GIP}=\frac{\text { control diameter }- \text { treatment diameter }}{\text { control diameter }} \times 100
$$

Data were submitted through variance and regression analysis using the software SISVAR v.4.0 (FERREIRA, 2000).

\section{RESULTS AND DISCUSSION}

Chemical constituents detected in the leaf extracts $\left(\mathrm{ExtH}_{2} \mathrm{O}\right.$ and ExtEtOH) indicated the same diversity of secondary metabolites (nine classes). However, the ethanolic extract, a solvent of less polarity than water, was more efficient in extracting these constituents, with an emphasis on alkaloids and phenolic compounds with higher frequency $(100 \%)$, followed by triterpenes, tannins, steroids, coumarins and flavonoids at $50 \%$ frequency (Figure $1)$.

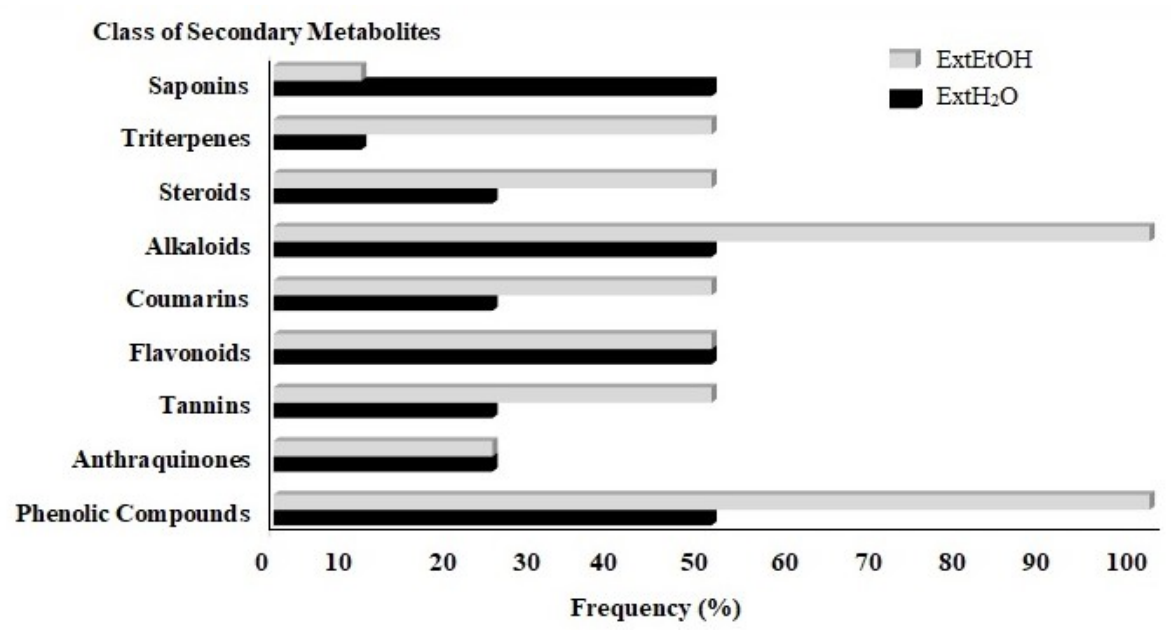

Figure 1. Frequency (\%) of secondary metabolites found in the aqueous extract $\left(\mathrm{ExtH}_{2} \mathrm{O}\right)$ and ethanolic extract (ExtEtOH) of Datura inoxia leaves.

Aqueous extract presented a lower frequency of secondary metabolites, being $50 \%$ for alkaloids, phenolic compounds, flavonoids and saponins; only the saponins showed a higher frequency in relation to ExtEtOH (Figure 1). The use of ethanol as an effective solvent for the extraction of phytochemicals has also been reported by Pereira et al. (2018), working with leaves of Anacardium humille A.St.-Hil, and reporting the presence of eight classes of metabolites.

Vernay et al. (2008) also pointed out alkaloids as major constituents in the leaves of $D$. inoxia, a specimen grown in France. Ayuba, Ojobe and Ayuba (2011) studied the leaves of specimens in India and found in addition to the alkaloids, the presence of phenolic compounds, flavonoids, saponins, cardiotonic heterosides and essential oils. The alkaloids and steroids were mentioned by Eftekhar, Yousefzadi and Tafakori (2005) for methanol extracts from the aerial parts of the investigated plant collected in Iran. Al-Sarai, Abbas and Al-Rekabi (2011), by analysing the ethanolic extract of leaves also collected in Iran, found a greater diversity of phytoconstituents (alkaloids, phenols, flavonoids, tannins, steroids, saponins, glycosides, and resins), which were attributed to in vitro antibacterial activity. Joshi and Kaur (2013), when investigating $D$. inoxia leaves collected randomly and aseptically from different areas of India found a greater diversity of secondary metabolites (alkaloids, phenolic compounds, flavonoids, tannins, terpenoids and steroids) in the aqueous extract in relation to the methanolic and ethanolic extracts (alkaloids, phenolic and flavonoid compounds and steroids). Recently, Bagewadi et al. (2019) determined that the phytochemical profiling of the methanolic leaf extract of D. inoxia collected in India revealed the occurrence of important phytochemicals, with a predominance of alkaloids in relation to the phenols, carbohydrates, flavonoids, saponins, and terpenoids.

Based on this information and our findings, it is possible to infer that the diversity of secondary metabolites and their frequency are related to the plants' origin and the extraction methods, because depending on these two factors significant differences in metabolites class may occur. According to Gobbo Neto and Lopes (2007) and Oliveira et al. (2017), there are several factors that may alter the presence of secondary metabolites, such as geographical location of the collection site, plant developmental stage, and the period of the 
Phytochemistry and antifungal...

year, among other factors, explaining the results found by this research.

In relation to the chemical profile by spectroscopy, alkaloid characteristic bands $(\lambda=230$ nm, Band $\mathrm{A}$ and $\lambda=260-270$, Band B) were observed, which confirms the tests performed with the use of specimen reagents and standards for alkaloids. In addition, it was reported for the species of the genus Datura the alkaloids of the tropane type, and for this chemical group, two electronic transitions with maximum absorption in the region of 230 and $275 \mathrm{~nm}$ were reported. The first band, corresponding to the electronic transition $\pi \rightarrow \pi^{*}$ of the benzoyl group and the second, the keto group (Figure 2).

Unlike the other secondary metabolites, alkaloids constitute a broad group of metabolites with great structural diversity, representing about $20 \%$ of the natural substances described and common in Solanaceae. Species of the Datura genus are known to be rich in tropane alkaloids, such as atropine ((8-methyl-8-azabicyclo[3.2.1]octan-3yl)3-hydroxy-2-phenylpropanoate), hyoscyamine (8-methyl-8-azabicyclo[3.2.1]oct-3-yl)3-hydroxy-2phenylpropanoate and scopolamine. This biological activity was related to the chemical structure of this group of substances (KLEIN-JÚNIOR; HENRIQUES, 2017; HERNANDES; KATO; BACCHI, 2017). According to Wittstock and Gershenzon (2001), the species produce alkaloids as a defence mechanism in response to herbivory and pathogen attacks.

Tropanes, like other alkaloids, possess a free pair of electrons on the nitrogen atom, which confers basicity and reactivity to these compounds. In general, alkaloids with pairs of free electrons have basic character (alkaline), soluble in solvents with polarity less than water and in polar solvents (KLEIN-JÚNIOR; HENRIQUES, 2017), which explains the higher frequency evidenced in the ExtEtOH (Figure 1).

It is possible to observe the bands $\mathrm{C}$ and $\mathrm{D}$ (Figure 2), common for the phenolic compounds $(\lambda=$ 280-300 $\mathrm{nm}$ ) and the $\mathrm{E}$ and $\mathrm{F}$ bands, related to flavonoids (entre $\lambda=320-390 \mathrm{~nm}$ ) (Figure 2). According to Zuanazzi, Montanha and Zucolotto (2017), for the flavonoids, it is common to observe two maximum bands of visible UV absorption, one being between $240-285 \mathrm{~nm}$ corresponding to ring A of the benzoyl system aromatic compounds with
MATIAS et al.

auxochromic substitution $(280 \mathrm{~nm})$ as the hydroxyl group, and another between 300-400 nm assigned to ring B of the cinnamoyl system. Similar results were found by Fatima et al. (2015) when investigating specimens of Pakistan, who detected on the leaves the flavonoids: catechin (279 nm), apigenin (325), and quercetin (368), which corroborates our findings. Also in this study, the antioxidant activity, visible protein kinase inhibitory activity against Streptomyces $85 \mathrm{E}$ strain with bald phenotype of 22 $\mathrm{mm}$, as well as the remarkable antimicrobial potential of leaf extract against Micrococcus luteus were related to flavonoids.

The soluble solid and the total phenolic and flavonoid content, obtained from the leaf $\mathrm{ExtH}_{2} \mathrm{O}$ and ExtEtOH of Datura inoxia (Table 1), has values of soluble solids higher than ExtEtOH, confirming the existence of substances groups dissolved in water, such as reducing sugars, phenolic acids, and saponins (Figure 1).

Regarding the phenolic compounds and derivates, a significant difference only occurred in total flavonoids, with their concentration being higher for the ExtEtOH. These results were higher than phenolic compounds (70.3 $\pm 1.1 \mathrm{mg}$ GAE/g) and total flavonoids (34.2 $\pm 1.3 \mathrm{mg} \mathrm{RE} / \mathrm{g})$ found by Bhardwaj, Kumar and Ojha (2016) for the methanolic extract obtained from the leaves of specimens collected in Haryana, India. However, our results were lower than those obtained by Nandakumar et al. (2017) for phenolic compounds $(3.62 \pm 0.0147 \mathrm{mg} / \mathrm{g})$ and flavonoids (4.12 \pm 0.0167 $\mathrm{mg} / \mathrm{g}$ ) found in Datura inoxia leaves collected in different regions of India (Orathanadu Village, Thanjavur District and Tamilnadu)

Concerning to the antifungal action, the ethanolic extract, which has a higher intensity of secondary phytochemicals (Figure 1) and total flavonoids (Table 2), provided 100\% inhibition of Sclerotinia sclerotiorum mycelial growth in all concentrations compared to the control (Figure 3). On the other hand, Fusarium solani growth was negatively affected only at the highest concentrations (2000 and $2400 \mu \mathrm{mL}^{-1} 100 \mathrm{~mL}^{-1}$ ).

The aqueous extract did not influence Fusarium solani growth. Nevertheless, for Sclerotinia sclerotiorum, inhibition values varied from 29 to $94 \%$, with the highest action concentrations being 1600 and $2000 \mu \mathrm{g} 100 \mathrm{~mL}^{-1}$, reaching 94\% inhibition (Figure 4). 


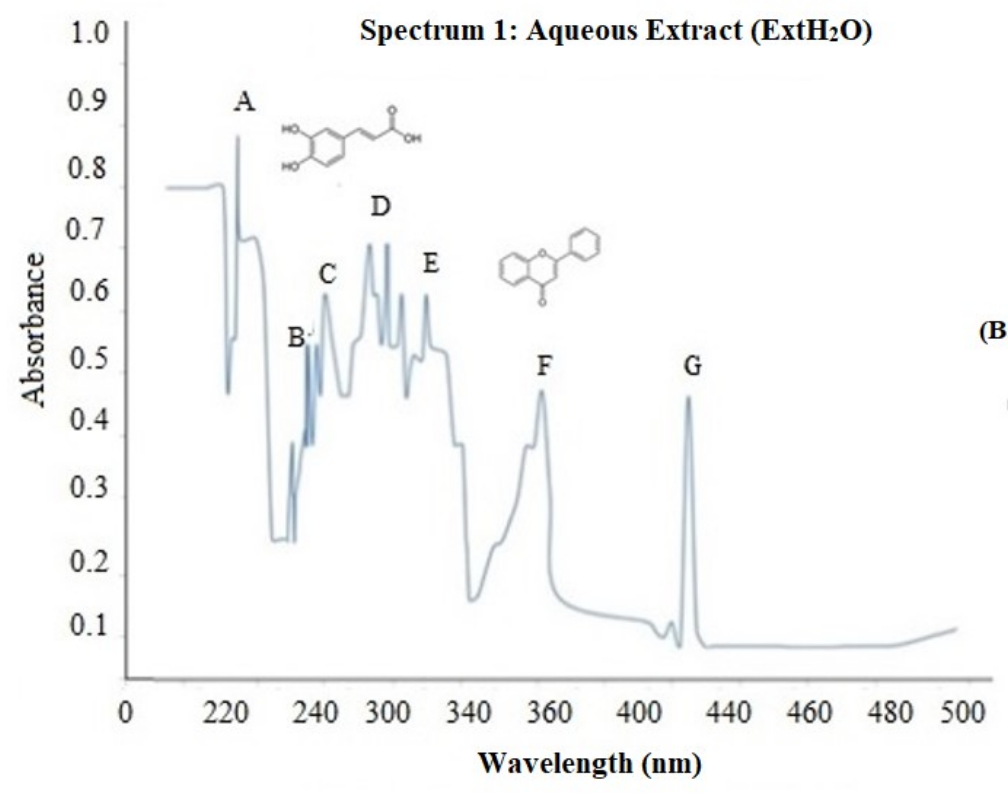

Alkaloids

(Band A and Band B)

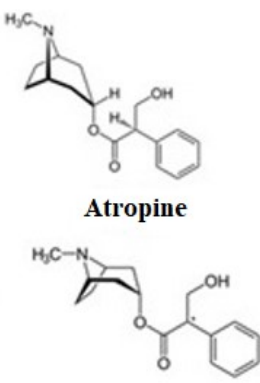

Hyoscymine
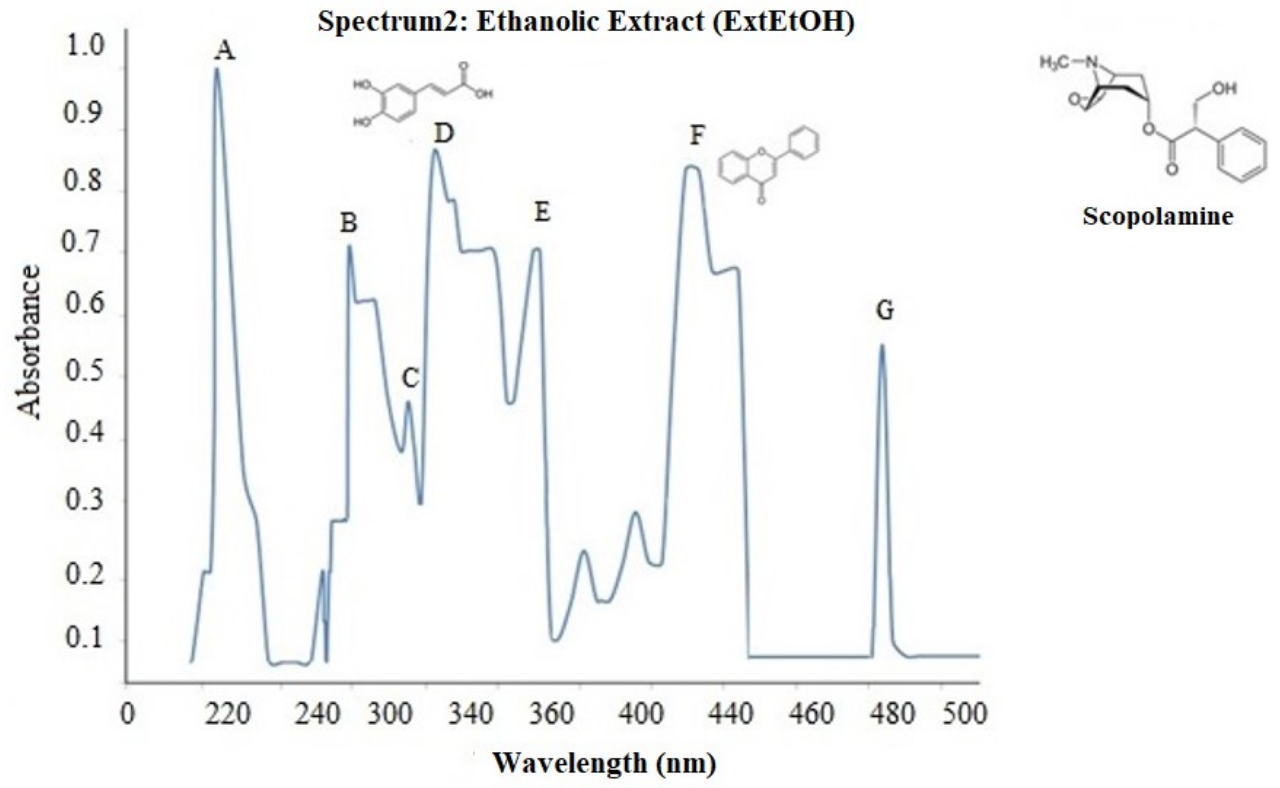

Figure 2. Absorption spectrum of the aqueous extract (Spectrum 1) and the ethanolic extract (Spectrum 2) of leaves of Datura inoxia.

Table 2. Soluble solids and the Total phenolic and Total flavonoid content obtained from the leaf aqueous and ethanolic extracts of Datura inoxia

\begin{tabular}{cccc}
\hline Extracts & $\begin{array}{c}\text { Soluble solid } \\
\left(\text { Brix 20 }^{\circ} \mathbf{C}\right)\end{array}$ & $\begin{array}{c}\text { Total phenolic } \\
(\mathbf{m g ~ G A E} / \mathbf{g})\end{array}$ & $\begin{array}{c}\text { Total flavonoid } \\
(\mathbf{m g ~ Q u e r c e t i n} / \mathbf{g})\end{array}$ \\
\hline $\mathrm{ExtH}_{2} \mathrm{O}$ & $5.0 \mathrm{a}$ & $492.8 \pm 0.0 \mathrm{a}$ & $93.9 \pm 0.0 \mathrm{~b}$ \\
$\mathrm{ExtEtOH}$ & $0.5 \mathrm{~b}$ & $472.5 \pm 0.8 \mathrm{a}$ & $248.3 \pm 0.0 \mathrm{a}$ \\
\hline
\end{tabular}

$\mathrm{GAE}=$ gallic acid. The averages followed by the same letter in the columns do not statistically differ by the Tukey test (p>0.05). 


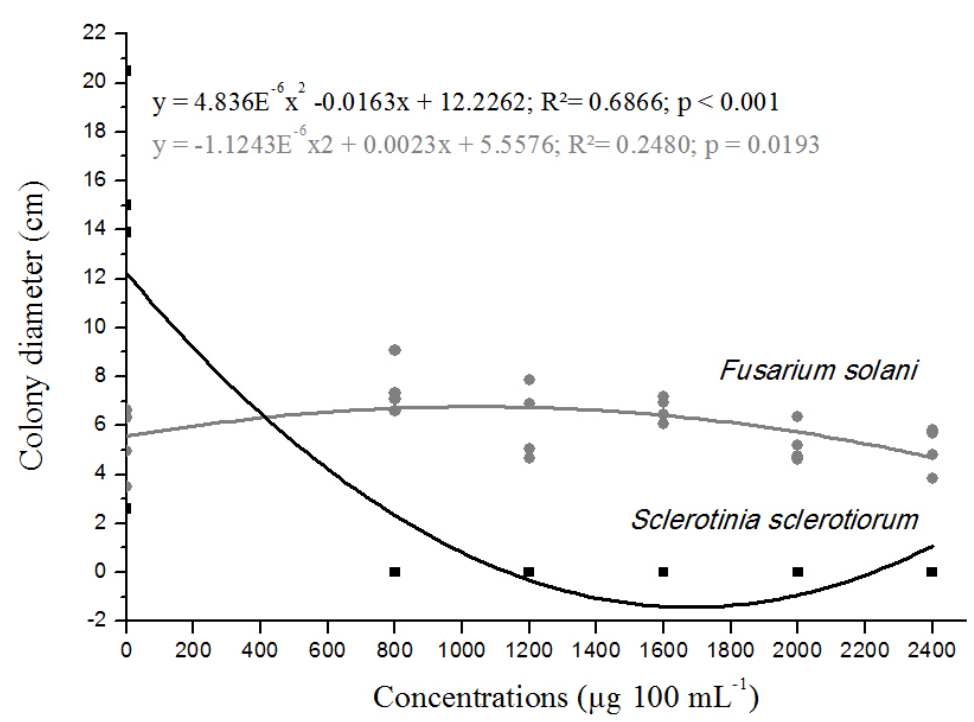

Figure 3. Mycelial growth inhibition of Fusarium solani and Sclerotinia sclerotiorum using different concentrations of Datura inoxia leaves ethanol extract.

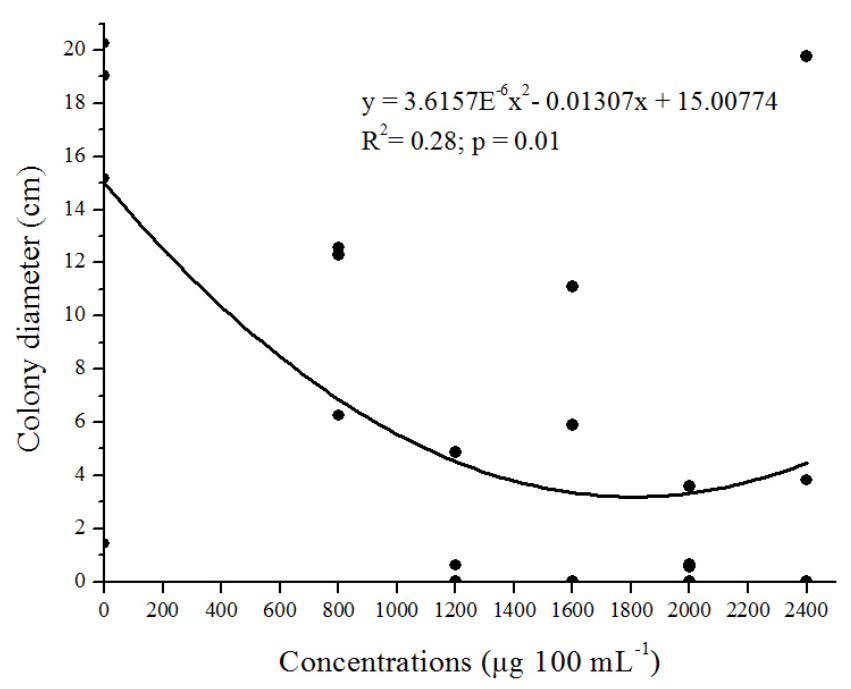

Figure 4. Mycelial growth inhibition of Sclerotinia sclerotiorum using different concentrations of the aqueous extract of Datura inoxia leaves.

The results showed that Sclerotinia sclerotiorum is more sensitive to the secondary metabolites of the aqueous and ethanolic extracts, even with lower extraction capacity solvents. It should be noted that flavonoids, with $50 \%$ intensity in both extracts, are an important metabolite in fungi control since these compounds act directly on cytoplasmic granulation, cellular contents disorganization, plasma membrane rupturing, and inhibition of enzymes produced by fungi in the moment of penetration into the host (KNAAK; FIUZA, 2010). Oliveira et al. (2017), evaluating different extracts and fractions of Pouteria ramiflora (Mart.) Radlk. on Lasiodiplodia theobromae growth, also correlated the lower rate of mycelial development with the presence of flavonoids in higher intensity.

The in vitro assays are performed to evaluate the inhibitory capacity of plant extracts on phytopathogenic fungi, and are essential to indicate which plant species may present potential use. In this situation, Datura inoxia stood out because of its diversity of metabolites.

The ExtEtOH completely inhibited mycelial growth of $S$. sclerotiorum, and it can be inferred that this action was due to the high concentration of 
phenolic compounds and alkaloids. These substances are directly related to the antifungal action and are able to act in a fungicide and/or fungistatic way. According to Gomes, Pena and Almeida (2016), these compounds, when present in plants extracts, present a potential inhibitor of mycelial growth, as well as acting on the germ tube emission of the phytopathogenic fungi, information that confirms the control efficiency observed in the present work. In addition, other compounds, such as triterpenes, extracted mainly in the ethanolic extract, also present direct action on fungal cells and, according to Stangarlin et al. (2011), inhibit spore germination and mycelial growth.

These substances are recognised by their fungicidal action since they can easily pass through fungus membrane cell, causing cellular contents extravasation (BARILE et al., 2007), which prevents mycelial growth and potential infection of phytopathogens in the host tissue (SCHWANESTRADA; STANGARLIN; PASCHOLATI, 2008). This action mode would contribute to the use of this extract in foliar spraying, to control pathogens that attack the aerial part of cultivated plants.

Taking into account the results obtained in vitro that demonstrated the potential use of the Datura inoxia species, new studies should be carried out under greenhouse conditions, with foliar spray or soil application, to observe the control capacity, as well as the reproducibility of the results observed under controlled conditions, since it was evident that the diversity of the constituents present in $D$. inoxia leaves, with a predominance of alkaloids and flavonoids, acted synergistically in the control of $F$. solani and $S$. sclerotiorum.

\section{CONCLUSIONS}

Datura inoxia extract provided mycelial growth inhibition of the fungi studied, with the ethanolic extract being more effective in the control of $F$. solani and $S$. sclerotiorum. The aqueous extract was efficient in reducing $S$. sclerotiorum growth.

Datura inoxia antifungal potential was probably related to the plant's chemical constitution, which has an abundance of alkaloids and phenolic compounds, related to the plant's defence system against invasive organisms, that negatively affected the development of the vegetative mycelium.

\section{ACKNOWLEDGEMENTS}

The authors are grateful to the National Council for Scientific and Technological Development $(\mathrm{CNPq})$ for providing the present research grant (PQ1d and PQ2), and to the Coordination for the Improvement of Higher Education Personnel (CAPES) for the master and doctoral level scholarships. We would also like to thank the Pantanal Research Center (CPP), National Institute of Science and Technology in the Wetlands (INAU), National Council for Scientific and Technological Development (CNPq/MCT), Foundation to Support the Development of Education, Science and Technology of the State of Mato Grosso do Sul (FUNDECT), and the University Anhanguera-Uniderp for funding the GIP project (Interdisciplinary Research Group).

RESUMO: A aplicação de defensivos químicos para o controle de doenças fúngicas tem por consequência impactos sobre o ambiente e a saúde humana. Desta forma, a utilização de extratos vegetais com propriedades antifúngicas associado ao manejo adequado de culturas, torna-se uma proposta viável de controle alternativo, principalmente na agricultura orgânica e familiar. Neste sentido, objetivou-se realizar a avaliação fitoquímica das folhas de Datura inoxia, avaliando seu potencial antifúngico frente ao crescimento micelial de Fusarium solani e Sclerotinia sclerotiorum. Os extratos, aquoso e etanólico, obtidos das folhas da planta coletadas em áreas do município de Campo Grande, Mato Grosso do Sul, foram submetidos à prospecção fitoquímica e quantificação flavonoides e fenóis totais, avaliando-se sua atividade antifúngica em concentrações de 800, 1200, 1600, 2000 e $2400 \mu \mathrm{g} 100 \mathrm{~mL}^{-1}$. Cada concentração foi incorporada, separadamente, em ágar BDA, vertida em placas de petri, seguida da colocação do disco de micélio do fungo, com diâmetro das colônias sendo medido diariamente. Utilizou-se como controle negativo, ágar sem extrato e ágar com solução etanólica. Nos dois extratos ocorreu a mesma diversidade de metabólitos secundários (nove classes); porém o extrato etanólico, um solvente de menor polaridade que a água, foi mais eficiente na extração destes constituintes, com destaque aos alcaloides e compostos fenólicos com maior frequência (100\%). Em relação a atividade antifúngica, o extrato etanólico proporcionou inibição de $100 \%$ do crescimento micelial de Sclerotinia sclerotitorum, em todas as concentrações, em relação a testemunha. Por outro lado, o crescimento de Fusarium solani foi afetado negativamente apenas nas maiores concentrações, 800 e $1200 \mu \mathrm{mL}^{-1} 100 \mathrm{~mL}^{-1}$. 
O potencial antifúngico da planta provavelmente está relacionado a sua constituição química, com abundância de alcaloides e compostos fenólicos, afetando negativamente o desenvolvimento do micélio vegetativo.

PALAVRAS-CHAVE: Fitofungicida. Compostos fenólicos. Fusarium solani. Sclerotinia sclerotiorum.

\section{REFERENCES}

AL-SARAI, A. A. H.; ABBAS, D. A.; AL-REKABI, F. M. K. Some toxicological impacts and in vitro antibacterial activity of Datura innoxia extract in rats. Kufa Journal for Veterinary Medical Sciences, Najaf, v. 2, n. 1, p. 132-145, 2011.

AYUBA, V. O.; OJOBE, T. O.; AYUBA, S. A. Phytochemical and proximate composition of Datura innoxia leaf, seed, stem, pod and root. Journal of Medicinal Plants Research, Academic Journals, v. 5, n. 14, p. 29522955, 2011.

BAGEWADI, Z. K.; MUDDAPUR, U. M.; MADIWAL, S. S.; MULLA, S. I.; KHAN, A. Biochemical and enzyme inhibitory attributes of methanolic leaf extract of Datura inoxia Mill. Environmental Sustainability, Springer, v. 2, n. 1, p. 75-87, 2019. https://doi.org/10.1007/s42398-019-00052-6

BARILE, E.; BONANOMI, G.; ANTIGNANI, V.; ZOLFAGHARI, B.; EBRAHIM SAJJADI, S.; SCALA, F.; LANZOTTI, V. Saponins from Allium minutiflorum with antifungal activity. Phytochemistry, Washington, v. 68, 596-603, 2007. https://doi.org/10.1016/j.phytochem.2006.10.009

BHARDWAJ, K.; KUMAR, S.; OJHA, S. Antioxidant activity and FT-IR analysis of Datura innoxia and Datura metel leaf and seed methanolic extracts. African Journal of Traditional, Complementary and Alternative Medicines, Lagos, v. 13, n. 5, p. 7-16, 2016.

BONDE, K. The genus Datura: From research subject to powerful hallucinogen. 2001. http://leda.lycaeum.org/Documents/The_Genus_Datura:_From_Research_Subject_to_Power. 9 p.

BUENO, C. J.; AMBRÓSIO, M. M. Q.; SOUZA, N. L. Produção e avaliação da sobrevivência de estruturas de resistência de fungos fitopatogênicos habitantes do solo. Summa Phytopathologica, Botucatu, v. 33, n. 1, p. 47-55, 2007. https://doi.org/10.1590/S0100-54052007000100007

BURKILL, H. M. The useful plants of West Tropical Africa. Vol. 5. $2^{\text {th }}$ edition. Kew: Royal Botanical Gardens, 2000. 686 p.

CELOTO, M. I. B.; PAPA, M. F. S.; SACRAMENTO, L. V. S.; CELOTO, F. J. Atividade antifúngica de extratos de plantas a Colletotrichum gloeosporioides. Acta Scientiarum Agronomy, Maringá, v. 30, n. 1, p. 15, 2008. https://doi.org/10.4025/actasciagron.v30i1.1104

EFTEKHAR, F.; YOUSEFZADI, M.; TAFAKORI, V. Antimicrobial activity of Datura innoxia and Datura stramonium. Fitoterapia, Elsevier, v. 76, n. 1, p. 118-120, 2005. https://doi.org/10.1016/j.fitote.2004.10.004

FATIMA, H.; KHAN, K.; ZIA, M.; UR-REHMAN, T.; MIRZA, B.; HAQ, I. U. Extraction optimization of medicinally important metabolites from Datura innoxia Mill.: an in vitro biological and phytochemical investigation. BMC Complementary and Alternative Medicine, United Kingdom, v. 15, n. 1, p. 376, 2015. https://doi.org/10.1186/s12906-015-0891-1

FERREIRA, D. F. Análises estatísticas por meio do SISVAR para Windows 4.0. In: REUNIÃO ANUAL DA REGIÃO BRASILEIRA DA SOCIEDADE INTERNACIONAL DE BIOMETRIA, 45., 2000, São Carlos. Anais... São Carlos: UFSCAR, 2000. p. 255-258. 
FLORA DO BRASIL 2020 em construção. Jardim Botânico do Rio de Janeiro. Disponível em: $<$ http://floradobrasil.jbrj.gov.br/ >. Acesso em: 06 Dez. 2017

FONTOURA, F. M.; MATIAS, R.; LUDWIG, J.; OLIVEIRA, A. K.M.; BONO, J. A. M.; MARTINS, P. F. R. B.; CORSINO, J. GUEDES, N. M. R. Seasonal effects and antifungal activity from bark chemical constituents of Sterculia apetala (Malvaceae) at Pantanal of Miranda, Mato Grosso do Sul, Brazil. Acta Amazonica, Manaus, v. 45, n. 3, p. 283-292, 2015. https://doi.org/10.1590/1809-4392201500011

GOBBO-NETO, L.; LOPES, N. P. Plantas medicinais: fatores de influência no conteúdo de metabólitos secundários. Química Nova, São Paulo, v. 30, n. 2, p. 374-381, 2007. https://doi.org/10.1590/S010040422007000200026

GOMES, E. M. C.; PENA, R. C. M.; ALMEIDA, S. S. M. Composição fitoquímica e ação fungicida de extratos brutos de Cinnamomum zeylanicum sobre Quambalaria eucalypti. Biota Amazônia, Macapá, v. 6, n. 4, p. 54-58, 2016. https://doi.org/10.18561/2179-5746/biotaamazonia.v6n4p54-58

GUPTA, M.; BAGCHI, A.; RAY, A. B. Additional withanolides of Datura metel. Journal of Natural Products, American Chemical Society, v. 54, n. 2, p. 599-602, 1991. https://doi.org/10.1021/np50074a042

HERNANDES, L. S.; KATO, E. T. M.; BACCHI, E. M. Alcaloides Tropânicos. In: SIMÕES, C. M. O.; SCHENKEL, E. P.; MENTZ, L. A. Farmacognosia: do produto natural ao medicamento. Porto Alegre: Artmed, 2017. p. 330-364.

JOSHI, M.; KAUR, S. In vitro evaluation of antimicrobial activity and phytochemical analysis of Calotropis procera, Eichhornia crassipes and Datura innoxia leaves. Asian Journal of Pharmaceutical and Clinical Research, India, v. 6, n. 5, p. 25-28, 2013.

KLEIN-JÚNIOR, L. C.; HENRIQUES, A. T. Alcaloides: generalidades e aspectos básicos. In: SIMÕES, C. M. O.; SCHENKEL, E. P.; MENTZ, L. A. Farmacognosia: do produto natural ao medicamento. Porto Alegre: Artmed, 2017. p. 305-315.

KNAAK, N.; FIUZA, L. M. Potencial de óleos essenciais de plantas no controle de insetos e microrganismos. Neotropical Biology and Conservation, São Leopoldo, v. 5, n. 2, p. 120-132, 2010.

https://doi.org/10.4013/nbc.2010.52.08

MATOS, F. J. A. Introdução a Fitoquímica Experimental. 2ed. Fortaleza: UFC, 2009, 141 p.

NANDAKUMAR, A.; VAGANAN, M. M.; SUNDARARAJU, P.; UDAYAKUMAR, R. Phytochemical analysis and nematicidal activity of ethanolic leaf extracts of Datura metel, Datura innoxia and Brugmansia suaveolens against Meloidogyne incognita. Asian Journal of Cell Biology, New York, v. 2, n. 4, p. 1-11, 2017. https://doi.org/10.9734/AJOB/2017/34241

OLIVEIRA, A. K. M.; RIZZI, E. S.; PEREIRA, K. C. L.; BONO, J. A. M.; PINA, J. C.; MATIAS, R. Phytochemical analysis and fungicide potential of Pouteria ramiflora against Lasiodiplodia theobromae. Horticultura Brasileira, Brasília, v. 35, n. 4, p. 564-570, 2017. https://doi.org/10.1590/s0102-053620170414

PADUA, J. B.; SCHLINDWEIN, M. M.; GOMES, E. P. Agricultura familiar e produção orgânica: uma análise comparativa considerando os dados dos censos de 1996 e 2006. Interações, Campo Grande, v. 14, n. 2, p. 225235, 2013. https://doi.org/10.1590/S1518-70122013000200009

PEIXOTO SOBRINHO, T. J. S.; SILVA, C. H. T. P.; NASCIMENTO, J. E.; MONTEIRO, J. M.; ALBUQUERQUE, U. P.; AMORIM, E. L. C. Validação de metodologia espectrofotométrica para quantificação dos flavonoides de Bauhinia cheilantha (Bongard) Steudel. Revista Brasileira de Ciências Farmacêuticas, São Paulo, v. 44, n. 4, p. 683-689, 2008. https://doi.org/10.1590/S1516-93322008000400015 
PEREIRA, K. C. L.; OLIVEIRA, A. K. M.; MATIAS, R.; RIZZI, E. S.; ROSA, A. C. Potencial alelopático do extrato etanólico de Anacardium humile A.St.-Hil. (cajuzinho-do-cerrado) na germinação e formação de plântulas de Lactuca sativa L. (alface), Lycopersicon esculentum Mill. (tomate) e Senna obtusifolia (L.) Irwin \& Barneby (fedegoso). Gaia Scientia, João Pessoa, v. 12, n. 2, p. 144-160, 2018.

https://doi.org/10.22478/ufpb.1981-1268.2018v12n2.37091

REMIÃO, J. O. R.; SIQUEIRA, A. J. S.; AZEVEDO, A. M. P. Bioquímica: guia de aulas práticas. Porto Alegre: EDI-PUCRS, 2003. 214 p.

SANGALLI, A. R.; SCHLINDWEIN, M. M. A contribuição da agricultura familiar para o desenvolvimento rural de Mato Grosso do Sul - Brasil. Revista REDES, Santa Cruz do Sul, v. 18, n. 3, p. 82-99, 2013.

SCHUlteS, R. E.; HOFMANN, A. Plants of the gods. Rochester: Healing Plants Press, 1992. 192 p.

SCHWAN-ESTRADA, K. R. F.; STANGARLIN, J. R.; PASCHOLATI, S. F. Mecanismos bioquímicos de defesa vegetal. In: PASCHOLATI, S. F.; LEITE, B.; STANGARLIN, J.R.; CIA, P. (Eds.). Interação planta patógeno - fisiologia, bioquímica e biologia molecular. Piracicaba: FEALQ, 2008. p. 227-248.

SILVA, A. C.; SALES, N. L. P; ARAÚJO, A. V.; CALDEIRA JÚNIOR, C. F. Efeito in vitro de compostos de plantas sobre o fungo Colletotrichum gloeosporioides Penz. isolado do maracujazeiro. Ciência e Agrotecnologia, Lavras, v. 33, p. 1853-1860, 2009. https://doi.org/10.1590/S1413-70542009000700026

SILVERSTEIN, R. M.; WEBSTER, F. X.; KIEMLE, D. J. Identificação espectrométrica de compostos orgânicos. 7ed. Rio de Janeiro: LTC, 2007. 490 p.

SIMÕES, C. M. O.; SCHENKEL, E. P.; MELLO, J. C. P.; MENTZ, L. A.; PETROVICK, P. R. Farmacognosia: do produto natural ao medicamento. Porto Alegre/Florianópolis: Artmed Editora, 2017. 486 p.

SOUSA, C. M. M. S.; ROCHA e SILVA, H.; VIEIRA-JR., G. M.; AYRES, M. C. C.; COSTA, C., L. S.; ARAÚJO, D. S.; CAVALCANTE, L. C. D.; BARROS, E. D. S.; ARAÚJO, P. B. M.; BRANDÃO, M. S.; CHAVES, M. H. Fenóis totais e atividade antioxidante de cinco plantas medicinais. Química Nova, São Paulo, v. 30, n. 2, p. 351-355, 2007. https://doi.org/10.1590/S0100-40422007000200021

VERNAY, P.; GAUTHIER-MOUSSARD, C.; JEAN, L.; BORDAS, F.; FAURE, O.; LEDOIGT, G.; HITMI, A. Effect of chromium species on phytochemical and physiological parameters in Datura innoxia. Chemosphere, Elsevier, v. 72, n. 5, p. 763-771, 2008.

https://doi.org/10.1016/j.chemosphere.2008.03.018

WITTSTOCK, U.; GERSHENZON, J. Constitutive plants toxins and their role in defense against hervivores and pathogens. Current Opinion in Plant Biology, Elsevier, v. 5, p. 1-8, 2001. https://doi.org/10.1016/S13695266(02)00264-9

ZACARONI, L. M.; CARDOSO, M. G.; SOUZA, P. E.; PIMENTEL, F. A.; GUIMARÃES, L. G. L.; SALGADO, A. P. S. P. Potencial fungitóxico do óleo essencial de Piper hispidinervum (pimenta longa) sobre os fungos fitopatogênicos Bipolaris sorokiniana, Fusarium oxysporum e Colletotrichum gloeosporioides. Acta Amazonica, Manaus, v. 39, n. 1, p. 193-198, 2009. https://doi.org/10.1590/S0044-59672009000100020

ZUANAZZI, J. A. S.; MONTANHA, J. A.; ZUCOLOTTO, S. M. Flavonoides. In: SIMÕES, C. M. O.; SCHENKEL, E. P.; MENTZ, L. A. Farmacognosia: do produto natural ao medicamento. Porto Alegre: Artmed, 2017. p. 209-233. 